\title{
INTRODUCTION OF A DROUGHT FORECASTING/ WARNING SYSTEM AND IMPROVEMENT METHODS IN THE REPUBLIC OF KOREA
}

\author{
HYEON-CHEOL YOON, JAE-CHAN AHN, GWAK YONG-SEOK \& BO-RA LEE \\ Disaster Prevention Research Division, National Disaster Management Research Institute, Korea
}

\begin{abstract}
With the occurrence of repeated drought damage, there has been a need for government-level R\&D support for scientific drought management from the mid-to long-term perspective in Korea. Because government agencies related to drought such as the Korea Meteorological Administration, Ministry of Land, Infrastructure and Transport, Ministry of Food, Agriculture, Forestry and Fisheries, and Ministry of Public Safety and Security, have been independently performing drought forecasting-warning, the president decided to establish integrated forecasting-warning system for drought prevention and effective drought management. In the present study, accordingly, we introduce the integrated drought forecasting-warning system in Korea. The Ministry of Public Safety and Security, as control tower, announces integrated drought information (Meteorological, Living and Industrial, Agricultural drought) to the public including investigation of local government situation. An announcement cycle is early of the month and target region is 167 provinces. Verification of drought information provided by each ministry was used by RDI. Final research purpose develops National Drought Information Integrated Forecasting-warning Technique Development. We expect that such efforts will be able to minimize drought damages and allow for pre-emptive prevention of droughts.
\end{abstract}

Keywords: drought, forecasting-warning system, RDI, National Drought Information.

\section{INTRODUCTION}

With the changes in precipitation and air temperature due to global warming, water balance pattern is expected to show significant imbalance and intensify global water shortage (Trenberth et al. [1], Burke et al. [2]). Frequency and severity of drought, a type of natural disaster that implies water shortage, are predicted to further increase because of the global climate change. Drought is progressed at a slow rate, and it is difficult to accurately define the start and end of drought. In addition, drought incurs tremendous social, economic and environmental expenses because of its complexity. Economic loss from drought is about 2-3 times as large as loss from flood, and 4 droughts that occurred in different places around the world were ranked among top five natural disasters of the 20th century selected by the National Oceanic and Atmospheric Administration (NOAA) of the United States. Also, in the disaster statistics announced by the National Drought Mitigation Center (NDMC) of the United States, drought damage was found to be largest in terms of average annual damage among different disaster types.

South Korea is vulnerable to drought because of meteorological condition in which about $70 \%$ of annual precipitation occurs in the summer flood season (from June to September) and topographical condition in which runoff occurs in short time on sharp riverbed slope. In South Korea, local drought occurs every 2 to 3 years cycle, and severe drought and water shortage occur at every 5 to 7 years. Actually, local restricted water supply was implemented and a dam with capacity of 200 million tons revealed its base after continuous droughts in 2014 and 2015. Damages are repeating every year as South Korea fails to come up with effective countermeasure and prevention method.

Since drought is a large-scale complex disaster that occurs on an annual basis, close cooperation among government bodies and relevant agencies is essentially required to 
prevent and appropriately cope with drought. As drought is organizationally related to meteorology, agriculture, hydrology, disaster prevention and environment, different government bodies need to cooperate and increase the nation's ability to cope with drought. Nations with advanced water control measures such as the United States, United Kingdom and Australia have established and enforced various standards and policies for drought stages according to climatic, environmental and socioeconomic situations of each nation. In such nations, the central government offers a general guideline for drought management and regional governments come up with specific and practical measures to prepare in a systematic way.

The United States provides information on drought research, drought mitigation measures and government activities through NDMC founded in 1995. In addition, various federal government departments such as the United States Geological Survey (USGS), NOAA and United States Department of Agriculture (USDA) are cooperating with NDMC to offer necessary information. The United Kingdom has established wide-area water companies to restrict water use. Relevant agencies (Department for Environment, Food and Agriculture, Environment Agency, water companies, local governments, etc.) are organically cooperating to make final drought decisions and come up with countermeasures. Also, Environment Agency analyzes various data related to water resource such as river water level, flow, monthly watershed precipitation and groundwater level (British Geological Society). Department of Agriculture, Fishery \& Forest is responsible in Australia, but most of agricultural policies including drought are under control of state governments.

On the contrary in South Korea, government agencies related to drought such as the Korea Meteorological Administration, Ministry of Land, Infrastructure and Transport, Ministry of Food, Agriculture, Forestry and Fisheries, and Ministry of Public Safety and Security have been independently performing drought forecasting and warning. As a result, they are focusing on response instead of prevention, and different government agencies are not cooperating properly. In addition, despite the necessity of quantitative evaluation, it was difficult to secure research and statistical data because of limited information disclosure among government bodies.

Accordingly, the government has recognized the need to prepare for a response to intensifying drought and decided to create an integrated forecasting and warning system for drought prevention.

In the present study, we introduced integrated drought forecasting-warning system in Korea and developed of Real time Drought Index(RDI) to verify the evaluation standard for drought each government department and finally proposed policy direction of government. The drought management of national dimension is expected to contribute to prevention of drought and to minimize damage.

\section{DROUGHT FORCASTING/WARNING SYSTEM IN KOREA}

\subsection{Operation plan of drought forecasting-warning}

In Korea, mutual cooperation is inadequate due to uncertainness of Role allocation each government department with absence of drought control tower. Therefore, immediate response was difficult and there was no drought prevention system in Korea in the early 2000s. Accordingly, the government announced the imposition' of 'relevant Ministry integrated drought forecasting-warning' since March 2016 to establish systematic response and counterplan for gradually increased extent of the damage of drought. 
The basic procedure is as follows. Drought forecasting-warning analysis data provided from "Korea Meteorological Administration", "Ministry of Land, Infrastructure and Transport" and "Ministry of Agriculture, Food and Rural Affairs", were verified and evaluated and compared with the drought condition of a local government by national Disaster management Research institute as a government-affiliated organization of "Ministry of Public safety and Security”. Finally, the results release the public.

The cycle of announcement of integrated drought forecasting-warning is a month and the detailed process is shown in Fig. 1.

Where drought forecasting-warning data proposed from "Korea Meteorological Administration", "Ministry of Land Infrastructure and Transport" and "Ministry of Agriculture, Food and Rural Affairs" to "Ministry of Public safety and Security" were shown in Fig. 2.

The drought information is composed of meteorological drought, hydrologic drought, agricultural drought. The alert level is made up of three stage such as normal (white), caution(yellow), severe(orange), extreme(red). Meteorological drought determines drought level based on accumulated precipitation over the most recent 6-month period. Hydrologic drought uses normal year storage of a dam as a criterion and agricultural drought uses both the available moisture capacity of the soil and the water reserve rates of agricultural reservoir and local government management reservoir as a criterion.

\subsection{Development of Real Time Drought Index (RDI)}

Despite enforcement of integrated drought forecasting-warning, the integration among drought information was needed because drought criterion each government department is different. Also, reliability evaluation, quantification and standardization for drought information which released each government department are needed.

In Korea, Palmer Drought Severity Index (PDSI, Palmer [3]) and Standardized Precipitation Index (SPI, Mckee et al. [4]) as meteorological drought index which means water shortages for precipitation have been used. Agricultural drought index have used Soil

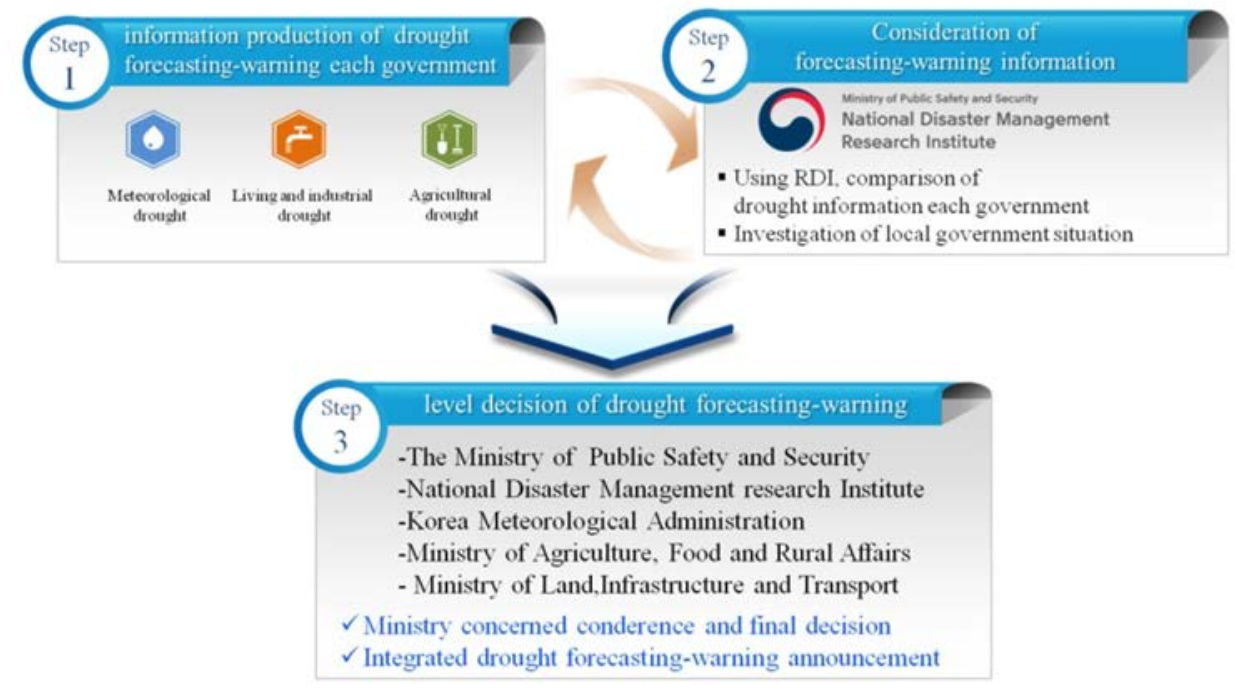

Figure 1: Process of drought forecasting-warning. 


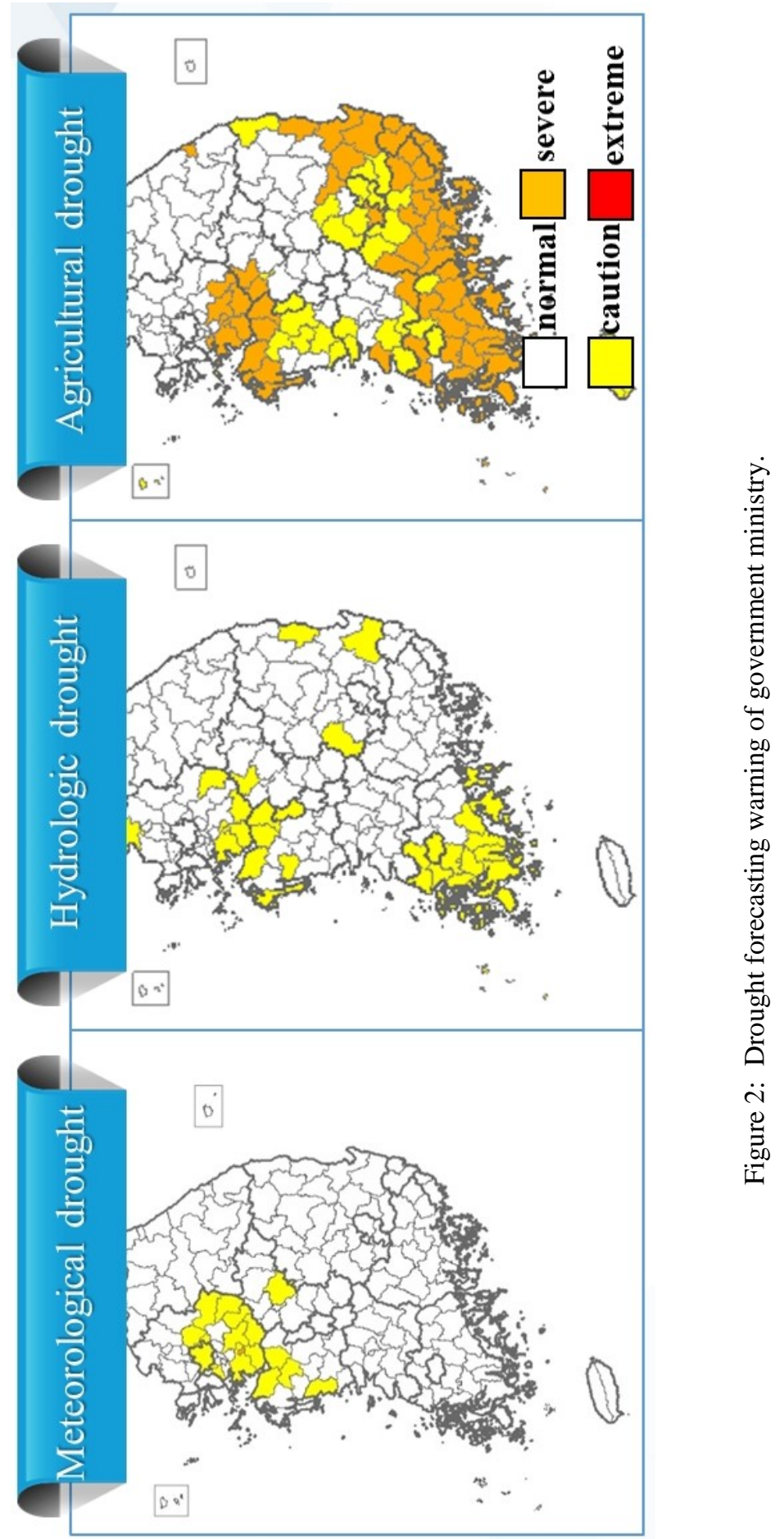


Moisture Drought Index, (SMDI, Hollinger et al. [5]) Crop Moisture Index (CMI, Palmer [6]) and hydrologic drought index have used representative Surface Water Supply Index (SWSI, Shafer and Dezman [7]).

Likewise, drought indexes used in general do not account for unbalanced supply and demand of living water, agricultural water and industrial water, which indicate actual degree of drought felt by human beings. Therefore, a national real time drought index was developed by considering supply and demand of living water, agricultural water and industrial water, (National Emergency Management [8]) suggesting a new concept of evaluation to interpret drought.

RDI is calculated using supply and demand of living water, agricultural water and industrial water in each administrative district. The system is subdivided into irrigation water supply and non-irrigation water supply as shown in Table 1.

As presented in Table 3, supply data of RDI applies river flow, dam and reservoir supply observed by each water supply agency. Artificial water supply system areas are classified into living intake water supply and agricultural reservoir water supply. Intake supply is comprised of river flow, living reservoir water and dam water.

Table 1: RDI system configuration.

\begin{tabular}{c|c|c}
\hline System division & Supply DB & Demand DB \\
\hline \hline Artificial supply system & $\begin{array}{c}\text { Dam, Reservoir, } \\
\text { river }\end{array}$ & $\begin{array}{c}\text { Demand of water supply and irrigation } \\
\text { regions }\end{array}$ \\
\hline Natural supply system & Precipitation & $\begin{array}{c}\text { Demand of non-water supply and non- } \\
\text { irrigation regions }\end{array}$ \\
\hline
\end{tabular}

Demand each water DB are shown in Table 2.

Table 2: DB composition of RDI demand.

\begin{tabular}{c|c|c}
\hline Division & Artificial supply system & Natural supply system \\
\hline \hline $\begin{array}{c}\text { Living } \\
\text { water }\end{array}$ & $\begin{array}{c}\text { Wide waterworks system, } \\
\text { local water service }\end{array}$ & Non-water supply \\
\hline $\begin{array}{c}\text { Industrial } \\
\text { water }\end{array}$ & $\begin{array}{c}\text { Planned industrial complex, } \\
\text { foot-loose industry }\end{array}$ & - \\
\hline $\begin{array}{c}\text { Agricultural } \\
\text { water }\end{array}$ & $\begin{array}{c}\text { Irrigated paddy(rice paddy, farm), } \\
\text { stockbreeding water }\end{array}$ & $\begin{array}{c}\text { Partially irrigated paddy } \\
\text { (rice paddy, farm) }\end{array}$ \\
\hline
\end{tabular}

Table 3: DB composition of RDI supply.

\begin{tabular}{c|c|c}
\hline Division & Artificial supply system & Natural supply system \\
\hline \hline Living water & $\begin{array}{c}\text { Dam, river, reservoir (living } \\
\text { and industrial) }\end{array}$ & $\begin{array}{c}\text { SPI (Standardized Precipitation } \\
\text { Index) }\end{array}$ \\
\cline { 1 - 2 } Industrial water & Reservoir (agricultural) & \\
\hline Agricultural water & Pan & \\
\hline
\end{tabular}


Computation of RDI uses the concept of water shortage. Whereas the artificial water supply system computes RDI as a ratio of demand to shortage (daily demand - daily supply), the natural water supply system computes water shortage using water demand data, regional parameter (A) considering seasonal characteristics, and minimum monthly SPI value (Table 4).

Drought class of RDI is computed and classified based on the ratio (shortage rate, D) of demand to shortage (demand - supply) for the artificial water supply system and natural water supply system. In case of the artificial water supply system, drought class is determined by the ratio of demand to shortage, which is demand minus supply. If there is no shortage, it is D0. If shortage occurs and the ratio of demand to shortage is below $25 \%$, it is D1. D2 is when the ratio is below $50 \%$, D3 is ratio below $75 \%$ and D4 is ratio of $75 \%$ or above. On the other hand, the natural water supply system classifies drought into two classes, D0 and D1. D0 is when water shortage does not occur and D1 is when water shortage occurs. When determining final drought class with RDI, it differs according to the results of drought class in the artificial water supply system and natural water supply system as in Table 5.

\section{IMPROVEMENT OF INTEGRATED DROUGHT MANAGEMENT POLICY AND PLAN}

National Disaster Management Research Institute is estimating drought forecasting-warning information which is presented from relevant Ministry by using RDI. Here, Korea will proceed with drought concerned policy to improve problems because two problems are detected. First of all, direct comparison and verification are difficult because spatial-temporal differences between RDI and drought criterion of government occur.

Table 4: Equation of RDI estimation.

\begin{tabular}{|c|c|c|c|}
\hline Division & $\begin{array}{l}\text { Artificial supply } \\
\text { system }\end{array}$ & \multicolumn{2}{|c|}{ Natural supply system } \\
\hline $\begin{array}{c}\text { RDI } \\
\text { estimation } \\
\text { equation }\end{array}$ & $\frac{\text { dailydemand - daily sup ply }}{\text { dailydemand }}$ & $\begin{array}{l}-\frac{\text { dailydemand }}{A-\left(S P I_{M}^{m}-1\right)}\left(S P I^{t}-A\right) \\
\text { A: regional parameter } \\
S P I_{M}^{m}: \text { minimum monthly SPI } \\
S P I^{t}: \text { the present } 90 \text {-day SPI }\end{array}$ & $\begin{array}{l}\text { nand-supply } \\
\overrightarrow{S P} I^{t}\end{array}$ \\
\hline
\end{tabular}

Table 5: Decision of drought index level of RDI.

\begin{tabular}{c|c|c|c|c|c}
\hline Division & D0(normal) & D1(weakness) & D2(middle) & D3(severe) & D4(extreme) \\
\hline \hline Artificial & $0 \geq \mathrm{D}$ & $0<\mathrm{D} \leq 0.25$ & $0.25<\mathrm{D} \leq 0.5$ & $0.5<\mathrm{D} \leq 0.75$ & $0.75<\mathrm{D}$ \\
\hline Natural & $0 \geq \mathrm{D}$ & $0 \leq \mathrm{D}$ & - & - & - \\
\hline Criteria & $\begin{array}{c}\text { Both } \\
\text { normal }\end{array}$ & At least one & Artificial & Artificial & Artificial \\
\hline
\end{tabular}

For more detailed contents, see National Emergency management (2013). 
Drought is determined based on definition of drought, which is shortage of average water resource level compared to average year. Meteorological drought (Korea Meteorological Administration) is determined as shortage of water compared to average year based on cumulative precipitation distribution during the same period between 1973 and the present. Agricultural drought (Ministry of Food, Agriculture, Forestry and Fisheries) is determined as temporal drought by considering shortage of water storage rate (quantity) in reservoirs compared to average year. Living and industrial drought (Ministry of Land, Infrastructure and Transport) is determined by considering reduction and limitation of supply based on water storage quantity (rate) that can sufficiently maintain river flow and supply living water, industrial water and agricultural water. On the contrary, RDI follows definition of water shortage that represents the relationship between social demand and currently available supply. Therefore, difference in the criteria for determining drought between government bodies and RDI is caused by roles and characteristics of different agencies such as timely fluctuation of water resources like precipitation, water supply management criteria, relationship between demand and supply, originating cause of drought and response to drought. The fundamental causes can be regarded as characteristics of drought and the lack of organized water management system. It is difficult to recognize direct and indirect social effects of drought, and there are no systems to analyze drought monitoring and water supplydemand network.

The primary cause of difference in the results of living water, industrial water and agricultural water between government bodies and RDI can be found in temporal perspective of water shortage (Fig. 3). Water shortage occurs when demand for water is greater than supply. Whereas RDI is based on time after occurrence of water shortage, government bodies are based on time before occurrence of water shortage. In other words, since government bodies evaluate drought when supply is greater than demand, showing difference in time of drought determination. For example, cautious or severe level of drought determined by government bodies in their drought forecast and warning can be classified as normal by RDI.

Since practical response to drought requires drought evaluation prior to occurrence of drought, it is necessary to recognize status of water resource before occurrence of water shortage and predict future droughts. Therefore, as preemptive drought response cannot be taken using the existing concept of RDI due to inability to compare it with drought forecast and warning of government bodies, it would be necessary to develop a modified standard for determining and computing RDI before occurrence of water shortage and apply the standard to integrated drought forecasting and warning.

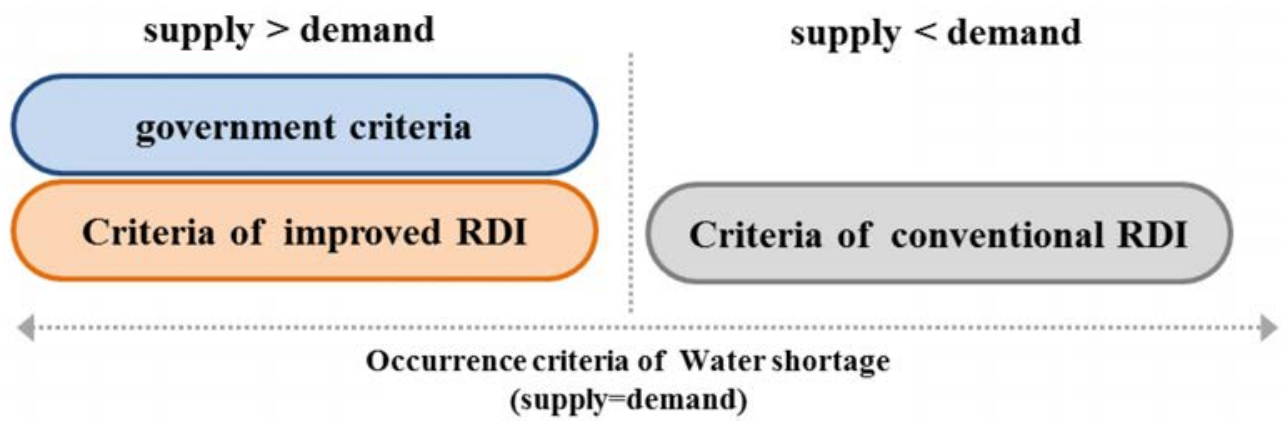

Figure 3: Improvement method of RDI. 
By making such improvements, different government bodies should disclose and share drought information to verify reliability and manage database in an organized way. The National Disaster Management Institute (NDMI) under the Ministry of Public Safety and Security plays the role of a drought control tower. It plans to provide real time drought information to citizens by operating a drought situation website.

\section{CONCLUSION}

The South Korean government has just started to respond to drought. The Ministry of Public Safety and Security is playing the central role in combining and analyzing drought information of different government bodies. Opinions are collected from persons in charge of drought in local government entities, and press releases on drought are distributed on a monthly basis.

Reliability of RDI combining drought analysis results of different government bodies will be improved through continued updates, and an objective drought standard will be developed to increase expertise of local government entities. Such efforts can minimize drought damages and allow for preemptive prevention of droughts.

\section{REFERENCES}

[1] Trenberth, K.E., Overpeck, J.T. \& Solomon, S., Exploring drought and its implications for the future. Eos, Transactions American Geophysical Union, 85(3), p. 27, 2004.

[2] Burke, E. J., Perry, R.H.J. \& Brown, S.J., An extreme value analysis of UK drought and projections of change in the future. Journal of Hydrology, 388, pp. 131-143, 2010.

[3] Palmer, W.C., Meteorologic Drought. US Department of Commerce, Weather Bureau, Research Paper No. 45, p. 58, 1965.

[4] Mckkee, T.B., Doeskin, N.J. \& Kleist, J., The relationship of drought frequency and duration to time scales. Proceedings of the 8th Conference on Applied Climatology, 1722 Jan., Anaheim, California, pp. 179-184, 1993.

[5] Hollinger, S.E., Isard, S.A. \& Welford, M.R., A new soil moisture drought index for predicting crop yields. Preprints, Eighth Conference on Applied Climatology, Amer. Meteor. Soc.: Anaheim, CA, pp. 187-190, 1993.

[6] Palmer, W.C., Keeping track of crop moisture conditions, nationwide: the new crop moisture index. Weatherwise, 21, pp. 156-161, 1968.

[7] Shafer, B.A. \& Dezman, L.E., Development of a surface water supply Index (SWSI) to access the severity of drought conditions in snowpack runoff areas. Preprints, Western Snow Conference, Colorado State University: Reno, NV, pp. 164-175, 1982.

[8] National Emergency Management, Establishment of National Drought Disaster Information System, NEMA-Nature-2011-40, 2013. 